\title{
RISMA AND AN INSIGHT OF IDEOLOGY IN POLITICAL POWER NARRATIVE
}

\author{
Inri Inggrit Indrayani \\ Department of Communication Science, Faculty of Communication Science, Petra Christian University \\ Jl. Siwalankerto 121-131, Surabaya 60236, INDONESIA \\ e-mail: inri.inggrit@petra.ac.id
}

\begin{abstract}
This study aims to determine the discourse in Tri Rismaharini's utterances as the first female mayor of Surabaya in a prominent talk show program. Woman with a strategic position in political domain is a rare phenomenon in a patriarchal culture. Risma is phenomenal one since not a party cadre, could be a major. As the public support becomes immensely increase of Risma's leadership. She was confronted a conflict of interests between political parties's and the public's. This condition raised issues about Risma's resignation. In an interview on a private television, Risma revealed about her feeling as leader of the city. How Risma conceives political power? How Risma practices political power? How she engages people to understand and be involved toward her policies? What about her political ideology? Risma's utterances on the program as a form of social act are interesting to be assessed. The method of this study is critical discourse analysis of Teun van Dijk. Van Dijk divides the analysis into three main parts which are the analysis of social, cognitive and discourse analysis. These analysis stages are used to examine the discourse in conversation or texts produced by a communicator. The analysis shows Risma puts political power as a divine mandate/transcendentalism. Secondly as women, Risma has implemented morality and justice as ethical politics further demonstrates masculinity through totality and accepts authority.
\end{abstract}

Keywords: Risma, political power, ideology, talk as a communication product, CDA.

\begin{abstract}
ABSTRAK
Penelitian ini bertujuan untuk mengetahui wacana dalam ucapan Tri Rismaharini sebagai walikota perempuan pertama Surabaya dalam program talk show. Wanita yang menduduki posisi strategis dalam politik merupakan fenomena langka dalam budaya patriarki. Risma merupakan fenomenal karena sekalipun bukan kader partai, bisa menjadi walikota. Sejalan dengan meningkatnya dukungan publik pada kepemimpinan Risma, dia dihadapkan dengan konflik kepentingan antara partai politik dan masyarakat. Kondisi ini mengangkat isu tentang pengunduran diri Risma. Dalam sebuah wawancara di televisi swasta, Risma mengungkapkan tentang perasaannya sebagai pemimpin kota. Bagaimana Risma memahami kekuasaan politik? Bagaimana Risma mempraktekkan kekuasaan politik? Bagaimana dia melibatkan masyarakat untuk memahami dan terlibat terhadap kebijakan nya? Bagaimana dengan ideologi politiknya? Ucapan Risma pada program sebagai bentuk tindakan sosial yang menarik untuk dikaji. Metode penelitian ini adalah analisis wacana kritis Teun van Dijk. Van Dijk membagi analisis menjadi tiga bagian utama yaitu analisis sosial, kognitif dan wacana. Tahap analisis ini digunakan untuk mengungkapkan wacana dalam percakapan atau teks yang diproduksi komunikator. Hasil analisis menunjukkan bahwa Risma menempatkan kekuasaan politik sebagai mandat Ilahi (transendentalisme). Kedua, sebagai perempuan, Risma mengimplementasikan moralitas dan keadilan sebagai politik etis, maskulinitas ditunjukkan melalui totalitas dan menerima semua kewenangan.
\end{abstract}

Kata kunci: Wanita Indonesia, kekuatan politik, CDA. ideology.

\section{INTRODUCTION}

Tri Rismaharini is special for Surabaya citizen. February 12, 2014, in the interview, Risma openly gave a statement about her decision to close the localization in Surabaya and her readiness to step down as the mayor of Surabaya. The broadcast both shocked the public and got sympathic response from the public.

Tri Rismaharini or commonly known as Risma is the first woman who serves as the mayor of Surabaya.
The position as the mayor of Surabaya is for 20102015 period. Risma is formerly known as the Head of Sanitation and Landscaping Department (DKP). Surabaya is a city that received a lot of awards under the leadership of Risma. Surabaya is also noted as the city that regained Adipura Cup 2011 and won numerous international awards, such as The 2013 Asian Townscape Sector Award from the United Nations for Bungkul Park. As the mayor, Risma also gained recognition among others, being nominated as one of the best mayors in the world at the 2012 World Mayor Prize, which was held by The City Mayors 
Foundation. (Source: Risma Super Wali, Majalah Detik, 9-15 September 2013)

Risma is also getting attention from various media including social media. Even on twitter, she becomes a trending topic in a few minutes. Appreciation also arises from a variety of public figures such as Buya Syafi'I Ma'arif former Chairman of Muhammadiyah who stated the mayor of Surabaya, Tri Rismaharini, is the ideal type of leader who has a vision and willingness to act. Risma is one of Indonesian women who managed to obtain public position with great supports from the community without being a member of a political party. Risma also has a more 'authentic' image compared to other female politicians.

Leadership of women in the political sphere will deal with power or authority. Power in politics is an important element in order to spread the influence and perform authority. Dianne Bystrom (2004:36) emphasized from the time a candidate contemplates her candidacy to the day of the election, she will be engaged in some aspect of communication, including interpersonal communications with party officials, campaign staff, the media, and voters; public speaking at rallies, news conferences, political conventions, and debates. Analysis of female candidates' communication during a political campaign reveals their styles and strategies in running for public office as well as offers a comparison with male candidates.

As a public official of Surabaya, Risma plays a central role in communicating her authority and public policy. In this case, good political communication is needed between the officials and the public. As identified by Denton and Woodward (1990, in McNair, 2011: 6), political communication is merely a discussion on the allocation of resources, authority and on the rewards and sanctions. Furthermore, Denton and Woodward also stress the importance of communicator or political actor's goal in influencing the political environment.

Communication strategy then is important to be studied in achieving the communicators' goals, including the language choice. In delivering the message, the communicator will attempt to construct and show their identity (Littlejohn and Foss, 2005:89). Brown (in Kendall and Tannen, 2003:551) explains that the languages chosen by men and women is a communication strategy for a human being is a rational creature who chooses languages to achieve social support in certain situations.

The previous research on the selection of language as a communication strategy ever conducted by Juraj
Horvath (2009) in "Critical Discourse Analysis of Obama's Political Discourse". The studies analyzed the ideology adopted by Barack Obama's inaugural speech as the president of United States. The study uses Norman Fairclough's critical discourse and the results showed that Obama's ideologies that had been used are pragmatism, liberalism, inclusion, acceptance of diversity and religious and ethnic unity.

Language and power have a close relationship. Language is a guide for the implementation of an ideology and a tool to instill an ideology in society as well. Language choice in any conversations can not be nullified, born without the cognition structure of the communicator. Communication and language styles of Risma are interesting to be analyzed as a social act that is capable of gaining participation and support from the public. As the public official who has a great influence in local politics in East Java, the implied discourses in the statements of Risma are also significant to be reviewed.

The language here is not understood as a neutral medium that lies beyond the speaker. Language in a critical view is understood as the representation that plays a role in shaping a particular subject, specific themes of discourse, as well as strategies in it. Van Dijk (2009: 13) also explains about the relationship between systematic discourses in conversations or expressions as a pragmatic form or language function. Statements, in Van Dijk's explanation, when made in certain situations are not only an expression of a person but also social acts, the same as firmness, a promise or a threat.

\subsection{Research Question}

Based on the explanation above, the research question of this study is:

How were Risma's communication strategies when she delivered the political power attached to her in Mata Najwa program on Metro TV on Wednesday, February 12th, 2014?

\section{LITERATURE REVIEW}

\subsection{Ideology, Discourse and Talk as a Communi- cation Product}

Ideology can not be separated from the discourse. Ideology is produced through discourse construction. Van Dijk (in Wenden. A and Schaffner. C) explains that ideology is articulated in a concept that links society, discourse and social cognition in the framework of critical discourse analysis. 
It is similar to the discourse that is formed through a process of social interaction and communication. Communication both verbal and non-verbal basically produces text. These texts are polysemy and can be found in images, movies, comics, media, conversation or other interaction products. Certain texts are not inadvertently but has contexts namely the organization or environment in the surrounding text.

Van Dijk (in Wenden, A. and Schaffner, C) further explains in this approach, ideology is the basic framework to regulate social cognition among members of social groups, organizations or institutions. In this case, the ideology includes both cognitive and social. Van Dijk offers an analysis called social cognition. In the analysis framework of Van Dijk, a research on social cognition is necessary: mental awareness of text makers that shape the text. To reveal how meaning is hidden in the text, we need an analysis of cognition and social context.

\subsection{Gender and Politics}

As a discourse, gender is multidisciplinary. Like many discussions related to gender inequality, power relations emerge as a starting point in the discussion relating to women in politics. In his book, Campus reviews the lack of women in political leadership. On the other hand, power is always associated with masculinity. Campus explores traditional assumptions about power, when people think about the power, the mind often leads to masculinity.

[H]istorically, the power of men has been public and visible, whereas when women had power, it was mostly covert and informal. This is particularly true for the field of politics and government, where until the past century women exerted their political influence only as a result of private relationships, whether as wives or mistresses. The only exception to the rule was a small group of reigning queens who inherited the crown in the absence of male heir.

(Campus, 2013: 11)

Identifying a discourse then requires the construction between language users with the text and all elements in the production of the text. A discourse is not 'out there', waiting to be marked. Gender discourse as a study emphasizes on the observations on the use of language. Language in the psychological approach produces cognition that can be explored through the practice of languages including the mental, and the importance of what is shown and orientation in the discussion of research subjects. In understanding the discourse related to this psychology, Weatherall said,
Languange itself is the object of enquiry because, consistent with social constructionism, language is understood as constructing, limiting and guiding people's understanding of their worlds and themselves. (dalam Sunderland, $2004: 28-29)$

Coates (1995: 13) explains that it is now widely accepted that women and men differ when speaking. Therefore, women and men make differences in the use of language resources available to them. Kendall and Deborah (2003) explains that the study of gender and discourse not only questions about the relationship between men and women, but also shows how language serves as a symbol to create and manage an identity, personal meaning, culture and social activities.

\section{METHODS}

In conducting the analysis, Van Dijk (in Wenden, A. and Schaffner, C) divides the text into three levels as the following:

1 Social Analysis, this level observes societal structures; institutional/organizational structures; group relations; group structures.

2 Cognitive Analysis, includes two levels of social cognition and personal cognition, namely:

Social cognition, this level observes sociocultural values; ideologies; systems of attitudes; Sociocultural knowledge.

Personal cognition, is divided in two focuses namely:

1. General (context free)

- Personal values: personal selections from social values

- Personal ideologies: personal interpretations of group ideologies

- Personal attitudes: systems of personal opinions

- Personal knowledge: biographical information, past experiences

2. Particular (context-bound)

- Models: ad hoc representations of specific current actions, events

- Context models: ad hoc representations of the speech context

- Mental plans and representation of (speech) acts, discourse

- Mental construction of text meaning from models: the text base

- Mental (strategic) selection of discourse structures (style, etc.)

3 Discourse Analysis, at this level the discourse is drawn from texts that have been analyzed in the previous level.

- The various structures of text and talk 


\section{FINDINGS AND ANALYSIS}

Based on Risma's statement or expression, there are three main sections which will be discussed. The statements or expressions show the ideology in Risma's discourse. In the discussion below, the ideology leads to the identity and purpose constructed by Risma to understand and execute her political power.

\subsection{Leaders with Divine authority}

When conceptualizing power, Risma emphasizes more the understanding that the public position which she is currently possessing is obtained from God. The power she has as the mayor is a mandate power that is theological or derived from the Divine. Being the mayor is a destiny for her; therefore, carrying out the responsibility and authority as the mayor is understood as a vertical accountability to God. Here is an excerpt of Risma's expression related to his position as the mayor.

I have thought once. For me, the position is a mandate so I cannot force.

If I cannot, it is ok. So, why should I force myself if I feel that I cannot do it?

Even though actually my family was not willing when I became the mayor, I did not expect that I could... That is it; suddenly I became the mayor. Ijust follow God's destiny.

I have told you ee.. that.. what is it. I surrender if it happens to me. Everything is just a mandate. It is up to God when He wants to take it. I do not know. That is the mystery of God.

Risma's statement above presents her identity as a religious leader so that spirituality is an aspect that can not be ignored when she interprets the social situations. The ups and downs as well as the obstacles she faces in carrying out the role of a public official are defined as a task given by the Creator. Therefore, her accountability is always oriented to the Creator as the One who gives trust or power. When power is interpreted as the extension of the Creator, the officials who run the power will be promoting the theological values than political practices, which emphasizes the position as a political force.

My background was not from any political parties. Maybe the way I think is different. Eee but I just hold my principle... my responsibility is the society of Surabaya is able to get more welfare and for that I must ....I will be responsible for what I have done in front of God.

Even though actually my family was not willing when I became the mayor, I did not expect that I could... That is it; suddenly I became the mayor. Ijust follow God's destiny.

Risma confirms that her background that was from non-political conditions differentiates her mindset and orientation with other public officials who incidentally are members of a political party. Risma's cognition gives an understanding that the money politic culture and the elite game are an inevitable problem in the selection of political candidates both locally and nationally. A huge economic capital is an instrument that limits a person entering into politics. The capacity of a person is not enough without the support of the elite and the economic capital. Public officials must also be able to perform and skillful at both lobbying and negotiations in the internal political party. Risma believed that she did not have economic capital. Risma believes more that leaders must obtain approval from the Lord through the voice of the people. The votes in the election obtained by Risma that reached more than $20 \%$ indicated she was a popular candidate and the public recognized her capacity. This then becomes the justification that being the mayor is a mandate.

In addition to identity, Risma's expressions also show there is a mission that must be completed by the time she served as the mayor of Surabaya. Authority and legitimacy attached to it are not given without a goal yet to address and resolve the intrinsic problem of the society namely becoming a prosperous society. This was revealed by Risma,

.... my responsibility is the society of Surabaya is able to get more welfare and for that I must ....I will be responsible for what I have done in front of God.

Eee what I know... what I know...ee how it moves faster... I do not know the style as long as it moves faster so that it is clear because the problems are a lot. When the problems are a lot, what is it called .... what I have to handle when it finishes, I handle another problem.

Running a position as a female leader is proven by Risma with her willingness to work hard and have totality as the mayor. Risma describes power as an access for Risma to make the society in Surabaya 
more prosperous. Her authoritative rights are used to make the condition in the much society better. This paradigm contradicts the numerous number of officials who use their power to satisfy their personal gain as much as possible.

\subsubsection{Leaders with morality}

Morality is a crucial aspect in understanding the transcendental ideology. One raised in the interview in Mata Najwa is Risma's courage against mainstream policy that was making a decision to close the prostitution area. The closing of prostitution area is very controversial. Politically, this is an unpopular policy. The existence of prostitution area is a chain of economy, which can not be resolved with just one approach. Risma's statement asserts that keeping morality is an important aspect that must be owned by a leader. In this context, the leader will mobilize all resources so that the public morality remains well preserved.

The beginning was a child trafficking case. One case when I traced.... I....impossible something to happen if she did not have any background. What was her background. Her background could be from family. Could be from school, could be from friends, could be from family. I traced that seriously. Then, I checked the family ... why the beginning.... I met her first... why? like this.... Then I traced her family.

I traced her school....then I traced her environment. That's... from me... eee found the same case again. Actually almost $90 \%$ of these kids had a relation with this area. It could be that she was from that area or even her parents were there. I do not know... She once lived there. Then I do not know... she was still living there. From that case then I went to school too.... I taught in those schools... so I had records that the child had a problem in that area....her school was there.... So, I went to that school so that it would not influence other children.

Risma in this case said that she traced correctly what is behind the problem of children trafficking. When morality becomes an important aspect in maintaining the social structure, the problem of children trafficking cannot simply be read as a violation of underage children working. Crucial violation in Risma's perspective is in the moral issue. Prostitution would threaten the future of the children's morality especially those living near the area of prostitution.
Before the closing of prostitution area has not been a city government official agenda. So far, there has never been a public official who frontally shows his attitude related to the problem of prostitution, except Tri Rismaharini. Risma's findings which then show that the prostitution and its area would damage the morale and the future lives of children encourage her to shut prostitution area as soon as possible. As a leader, it becomes very clear that Risma's stand lies on the importance of young people as a pillar of the nation. The failure of leadership lies in its failure to prepare the children as the future of the nation.

As a female leader, Risma explained that she stressed on the importance of intuition rather than mathematical logic. Risma believed that intuition is the medium of God to open something.

Nah...then from that once again... eee I think maybe that is I follow because I follow my consciousness. That is what God shows.

Then I ask again, Ma'am sorry. Once again I apologize if I am wrong.... You are old so who is your custome.... Thatbut maybe it is God's way.

Risma also indicates that in solving a case, she always listens to intuition and sensitivity. Intuitive leaders tend to assess their concerns deeper. In this context, consideration based on the logic is not solely used by Risma. In contrast, Risma relies more on intuition in observing and assessing a problem. Once again, intuition is the voice channel of God to her.

Social cognition built by Risma is the mentality that the problem of prostitution is not just businesses that violate social norms and religious teachings, but if prostitution is tolerated, it can damage the moral and kill the educational and healthy environment for children as the future generations. Carol Gilligan (1982 in White, 1999: 463-464) explains that women and men have different conceptions of problems related to moral. Moral problems are seen by women in terms of relationships, caring and compassion. Handling the problem of prostitution, Risma asserts herself as a leader who acts as a moral guardian with due respect to the absence of a moral violation that occurs in children.

\subsubsection{Leaders with a fair character}

According to Risma, being fair is a value that is appropriate owned by a leader. In the analysis of social and social cognition, Risma puts the mayor as 
the representation of the country at the level of city government. In the implementation of the policy, the state is often assumed not able to be fair in resolving the problem. The state has even done the abuse of power by giving priority to certain interest groups, but pressing other interests. Conflict and crisis related to public policy happen because of the powerless leaders of state institutions in each line to manage differences in opinion or discourse in the grassroots level. Here Risma's explanation,

Once I became the mayor, I could not..ee what is it called..ee I must be fair. The problem is it is difficult. So I cannot differentiate the rich, the poor, the black, the white... ee it is not allowed. This is old, this is young, small, big.. like that ... it is not allowed. That is why it is difficult. The most difficult is because I must be fair.

Authority inherent in the Risma's position is articulated to be fair. Risma puts social justice as a guarantee given by the government to citizens for obtaining the same rights in the fields of politics, economics and law. Identity that women tend to play with their feelings and be emotional in making decisions becomes counterproductive to Risma. Risma's masculine perspective through her bravery is shown by her attitude of being impersonal male justice (Gilligan, ibid).

\section{DISCUSSION}

At least there are two things that can be highlighted in this study regarding the discourse conveyed by Risma's statements:

First, political power is basically a manifestation of divine power. Risma asserts that a person who has a political position should be aware of the concept so that power should not be contested because transcenddentally power will go to someone who is deemed worthy of the divine mandate. This concept is different from the concept of political theology, which raises the doctrine of "divine right of kings". In this term, the power of a king is a manifestation of divine power. This concept is adopted in the monarchist government system, so that the king's decision is considered to represent the voice of God. In the context of countries that embrace democratic system, Risma emphasizes transcendental discourse on spiritual values and morality aspects of leadership and social justice as a character in carrying out the policy.

Second, the power relations between women and politics are ethical. In a country that is still patriarchal, politics is a masculine domain. Women in politics naturally are placed in the position of second class. As a public official who is actually a woman, this is a social construction that can not be rejected or denied by Risma. Risma's expressions strengthen this construction through her emotional nature in dealing with problems of the city, her inability to speak diplomatically and politically, over what is and is not working to build her image. On the other hand, Risma's political power as a public official is emphasized by knowing that Risma were not born from a trick or elite party game but from her competitive nature. Risma political capital was not in fact the economic capital that becomes the substance in local elections. Instead, Risma emphasizes the importance of social capital as a ethical manifestation in politics to be possessed by a leader. Femininity is shown by Risma through ethical political behavior while masculinity is shown through justice that suppresses the rule, procedures and physical work.

Trancendentalism and ethical politics as ideologies are not merely produced without any reasons. Local political context as a representation of national politics which is full of unfair competition and political masculinity as a patriarchal social cultural product than become the background of Risma ideology. It is in line with Teun Van Dijk (2009:25) who explained that the context of communication activities thus aligned with the existing social situation.

\section{After all, contexts as mental models of relevant communicative situations are not just personal interpretations of situations, but are also based on socially shared understandings of time, place, participants and their roles and identities, relations of power, and so on.}

The narrative of Political power is conviced by Risma as the struggle of devoting to God's mandate. The narrative is the counter of the polical power mainstream that pursued materialism and power maintainance only. As a woman leader and mayor, Risma also emphasized the importance of morality and justice as the cores of ethics in politics.

\section{CONCLUSION}

Communication strategy chosen by Risma in Mata Najwa program to gain public understanding of her political attitudes is to emphasize her identity as a religious leader, promote morality and become a fair leader. When these values are emphasized, the transcendental discourse and social justice become a system of values held by Risma in defining and 
running power. As women, ethical politics is a political character adopted by Risma as the reaction to the pragmatic politics run by masculine. Nevertheless, masculinity is still shown by Risma through work ethic, assertiveness in carrying out public policy, the rational management of the city and ability to cope with jobs that require strong physical power.

\section{REFERENCES}

Brown, P dalam McConnell-Ginet dalam Kendall dan Tannen.(2003). Discourse and Gender dalam The Handbook of Discourse Analysis. Victoria: Blackwell Publishing.

Bystrom, D. (2004). "Handbook of Political Communication Research". New Jersey: Lawrence Erlbaum Associates.

Campus, (2013). Women Political Leaders and the Media. New York: Palgrave Macmillan.

Coates, J. (1995), "language, Gender and Career" dalam "Language and Gender". England: Longman Group.

Denton \& Woodward. (1991). Dalam McNair, B. (2010). "An Introduction To Political Communication". New York: Routledge.
Horváth, J. (2009). "Critical discourse analysis of Obama's political discourse". http://www.cs. columbia.edu/ sbenus/Teaching/APTD/Horvath _CDO_Obama.pdf

Gilligan, C. in White, R.D. (1999). "Are Women More Ethical ?", Journal of Public Administration Research and Theory, 9 (3), 459-471.

Kendall, S., dan Tannen. (2003). "Discourse and Gender" dalam "The Handbook of Discourse Analysis". Victoria : Blackwell Publishing.

Littlejohn, S. and Foss, K.A. (2005). "Theories of Human Communication". Canada: Thomson.

Napsiah, (2009). Nilai-Nilai Profetik dan Affirmative Action di Partai Politik dalam Gender and Politics. Yogyakarta: Tiara Wacana.

Van Dijk, T. (2009), Society \& Discourse: How Social Context Influence Text and Talk. New York: Cambridge University Press.

Van Dijk, T. (1995). Discourse Analysis as Ideology Analysis, dalam Wenden, A. and Schaffner, C. (eds) Languange and Peace (in press).

Sundeland, J. (2004). "Gendered Discourses". New York: Palgrave Macmillan.

Risma Super Wali, Detik Magazine, September, $9^{\text {th }}$ $15^{\text {th }}, 2013$ 